\title{
Quality of water used for drip irrigation and fertigation of horticultural plants
}

\author{
Wlodzimierz Breś, Tomasz Kleiber, Tomasz Trelka \\ Department of Horticultural Plant Nutrition \\ Poznan University of Life Sciences \\ Zgorzelecka 4, 60-198 Poznan, Poland \\ e-mail:wbnaw@up.poznan.pl
}

\begin{abstract}
In the years 1997-2008, 131 water samples were analysed. The concentration of $\mathrm{N}_{-} \mathrm{NH}_{4}, \mathrm{~N}_{-} \mathrm{NO}_{3}, \mathrm{P}, \mathrm{K}, \mathrm{Ca}, \mathrm{Mg}$, $\mathrm{Na}, \mathrm{Cl}, \mathrm{S}_{-} \mathrm{SO}_{4}, \mathrm{Fe}, \mathrm{Mn}, \mathrm{Zn}, \mathrm{Cu}, \mathrm{B}$, and $\mathrm{HCO}_{3}^{-}$was measured. In addition, the $\mathrm{pH}$ value and the electrolytic conductivity (EC) were determined and the sodium adsorption ratio (SAR) was calculated. The assessment of water was done on the basis of the classifications of water for the irrigation of greenhouse crops grown in soil or traditional media. According to guide values, water samples had to have high concentration of ions, especially $\mathrm{HCO}_{3}, \mathrm{Mg}, \mathrm{Na}$ and $\mathrm{K}$. The questioned quality in about one half of the water indicates that the limits proposed by different researchers are too restrictive. The criteria to be met by water admissible for irrigation and fertigation should take into consideration the regional differences in water characteristics. The adaptation of recommendations elaborated on the basis of analyses originating from other geographical and geological regions can lead to the elimination of waters possessing favourable quality parameters. For irrigation of field and greenhouse crops, the following concentrations of components in water might be recommended as safe ones: $30 \mathrm{mg} \mathrm{N}-\mathrm{NO}_{3}, 100 \mathrm{mg} \mathrm{K}, 150 \mathrm{mg} \mathrm{Ca}, 50 \mathrm{mg} \mathrm{Mg}, 100 \mathrm{mg} \mathrm{Na}, 100 \mathrm{mg} \mathrm{Cl}$ and $100 \mathrm{mg} \mathrm{S}-\mathrm{SO}_{4}$ in $1 \mathrm{dm}^{3}$. For soilless culture fertigation in an open system, the maximum ion concentrations in water cannot exceed the recommended ones in the nutrient solution for the given plant. Also, the EC value should be taken into consideration.
\end{abstract}

Key words: horticultural crops, ions concentration, quality guidelines

\section{INTRODUCTION}

The history of irrigation development can be traced back to prehistoric times. Modern drip irrigation began its development in Afghanistan in 1866, where experiments with irrigation using clay pipes began. Fertigation, i.e. irrigation combined with fertilization, has been used for almost 50 years. The high potential efficiency of fertigation results from the possibility of using the optimal concentration of nutrients and a high density of roots in the moistened soil zone (Bar-Yosef and Sagiv 1982, Bravdo 1993). Due to fertigation, it is possible to create fertilization programs based on the optimal nutrient solution concentrations for plants and on the proper ratio between the ions. The application of fertilizers and water through an irrigation system requires a consideration of plant needs, soil properties and technological requirements of the fertigation system. The basic element is the water quality. The higher the plant requirements and the technologically advanced system, the higher are the quality demands. Unfortunately, recommendations from different researchers are divergent. The present research tries to assess the practical suitability of the different recommendations.

\section{MATERIAL AND METHODS}

In the years 1997-2008, 131 water samples were analysed. The samples originated from underground water intakes belonging to horticultural farms 
localised in the Wielkopolskie, Dolnośląskie and Lubuskie provinces. Water was sampled into plastic bottles during plant irrigation in spring. In the studied waters, the concentration of the following ions was measured: $\mathrm{N}_{-\mathrm{NH}_{4}}, \mathrm{~N}^{-\mathrm{NO}_{3}}, \mathrm{P}, \mathrm{K}, \mathrm{Ca}, \mathrm{Mg}$, $\mathrm{Na}, \mathrm{Cl}, \mathrm{S}_{-} \mathrm{SO}_{4}, \mathrm{Fe}, \mathrm{Mn}, \mathrm{Zn}, \mathrm{Cu}, \mathrm{B}$, and $\mathrm{HCO}_{3}^{-}$. The following analytical methods were used: $\mathrm{N}-$ by the distillation method of Bremner modified by Starck; $\mathrm{P}$ - by the colorimetric method with molybdate ammonium; K, $\mathrm{Ca}, \mathrm{Mg}, \mathrm{Na}, \mathrm{Fe}, \mathrm{Mn}, \mathrm{Zn}, \mathrm{Cu}-$ by the AAS method; $\mathrm{S}$ and $\mathrm{Cl}$ were determined nephelometrically with $\mathrm{BaCl}_{2}$ and $\mathrm{AgNO}_{3}$, respectively; $\mathrm{B}$ - by the colorimetric method with curcumin; bicarbonates - by the titration method (Jackson 1958, Elbanowska et al. 1999, Breś et al. 2009). Furthermore, the $\mathrm{pH}$ value and the electrolytic conductivity (EC) were determined. The sodium adsorption ratio (SAR) was calculated according to the following formula:

$$
S A R=\frac{N a}{\sqrt{\frac{(C a+M g)}{2}}}
$$

where ionic concentrations are in $\mathrm{mmol} \mathrm{dm}^{-3}$.

Sodium hazard was defined separately because of its specifically detrimental effects on soil properties. Calcium flocculates, while sodium disperses soil particles. Dispersed soil readily crusts, thereby impeding water infiltration (Bauder et al. 2009).

Assessment of waters was done on the basis of the classifications of water for the irrigation of greenhouse crops grown in soil or in media according to Flood (1996) and Bailey et al. (1999).

\section{RESULTS AND DISCUSSION}

The eutrophication of water reduces the quality of surface waters, excluding their utilisation for irrigation. Not enough precipitation is also not without significance, especially during the growing season. This is the reason why in horticulture underground waters are often utilised. The chemical constituents of irrigation water can affect plant growth directly through toxicity or deficiency, or indirectly by altering nutrient availability for plants. The characteristics of irrigation water defining its quality vary depending on the water source. Regional differences in water characteristics exist, based mainly on geology and climate. The basic legal act containing water classification in Poland is the Regulation issued by of the Minister of Environment of 11 February 2004 (Dz. U.
$32 / 1734,2004)$. The quality of underground water is defined on the basis of 36 indicators including the content of phenols, superficially active substances and nitrogen polycyclic aromatic compounds. In the mentioned Regulation, five classes are distinguished, however, without the specification of waters for irrigation. The assessment of water destined for horticulture does not require such a thorough detailed analysis. Usually, only several parameters mentioned in the chapter "Material and Methods" are measured and calculated. More detailed analyses are carried out only in cases when there are some suspicions regarding the presence of noxious compounds or ions. Results of the basic chemical analyses of 131 water samples from wells of horticultural farms are shown in Figures 1 and 2. Concentrations of elements oscillated within very wide ranges. The highest differentiations were recorded for $\mathrm{S}_{-} \mathrm{SO}_{4}, \mathrm{Mg}$ and $\mathrm{HCO}_{3}^{-}$, while the most equalized concentrations were found in $\mathrm{P}, \mathrm{Fe}, \mathrm{Zn}$, $\mathrm{Cu}, \mathrm{B}$ and in the results of $\mathrm{pH}$ measurements. The concentration of $\mathrm{N}^{-\mathrm{NH}_{4}}$ did not exceed $2.45 \mathrm{mg}$ $\mathrm{dm}^{-3}$ (data not presented). At the same time, $81 \%$ of water samples contained less than $10 \mathrm{mg} \mathrm{N}-\mathrm{NO}_{3}$ $\mathrm{dm}^{-3}$.

The most commonly known criteria for water quality assessment intended for plant irrigation were published in the form of a document by the Food and Agriculture Organization of the United Nations in the year 1976 (Ayers and Westcot 1994). In successive years, the criteria were modified; however, there were no separate indications for horticultural crops (Vomocil and Hart 1990). Separate guide values for greenhouse irrigation water were published by Flood (1996). Quality assessments of the studied water samples, according to Flood's recommendation, are shown in Table 1. The most difficult requirements to be met include those referring to $\mathrm{HCO}_{3}{ }^{-}$and $\mathrm{Mg}$ concentrations, while the easiest ones include $\mathrm{S}_{-} \mathrm{SO}_{4}, \mathrm{Cu}, \mathrm{B}, \mathrm{Fe}, \mathrm{Mn}$, $\mathrm{Ca}$ and SAR. Although the highest concentration of sodium was $148.3 \mathrm{mg} \mathrm{dm}^{-3}$, SAR does exceed 2.6. Unfortunately, the guidelines shown in Table 1 are not fully useful for horticultural needs. Too many water samples would have to be disqualified. For example, according to Flood (1996), 56\% of waters contain too much sulphur and $99-100 \%$ water samples showed too much $\mathrm{HCO}_{3}^{-}$. The recommended maximum admissible $\mathrm{pH}$ values are also questionable. For bicarbonates, the recommendations of Westcot and Ayers (1994) are more practical. The mentioned authors call attention to the following restrictions: in the case 


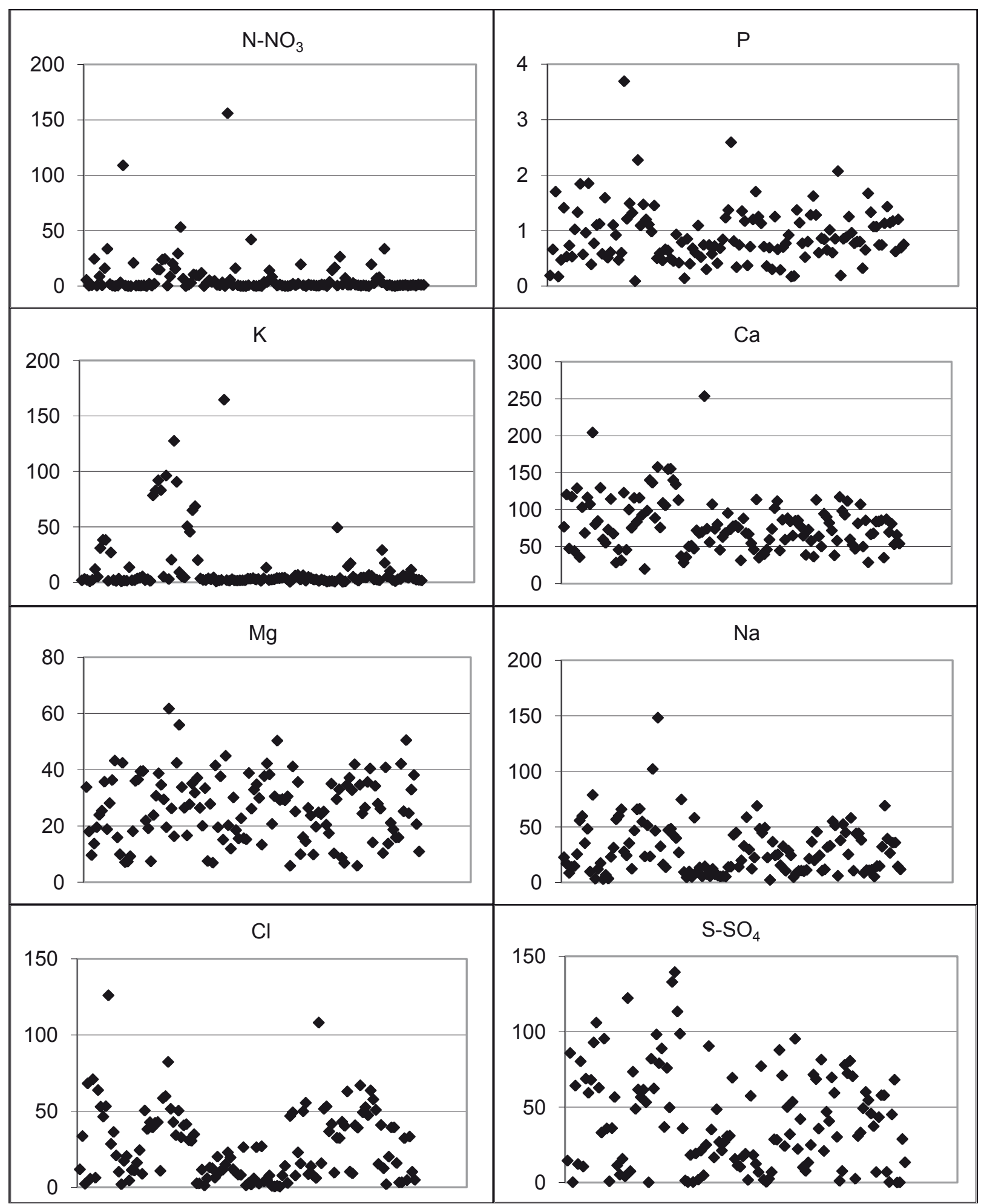

Figure 1. Chemical composition of water samples $\left(\mathrm{mg} \mathrm{dm}^{-3}\right)$

of a 90-500 mg $\mathrm{HCO}_{3}^{-} \mathrm{dm}^{-3}$ concentration, the threat is slight to moderate; a higher concentration than $500 \mathrm{mg} \mathrm{HCO}_{3}^{-} \mathrm{dm}^{-3}$ is severe for the plants. Potential irrigation problems concern unsightly foliar deposits. A high bicarbonate level can also increase soil $\mathrm{pH}$, and in combination with carbonate they may affect soil permeability.
Given the current state of knowledge, the concentrations of 2 and $5 \mathrm{mg} \mathrm{Fe} \mathrm{dm}^{-3}$ for greenhouse irrigation and for containerised nursery crops are too high. In addition, determination of minimal values must be regarded as unnecessary because fertilizers can easily supplement the absence of a required component. On the other hand, the 


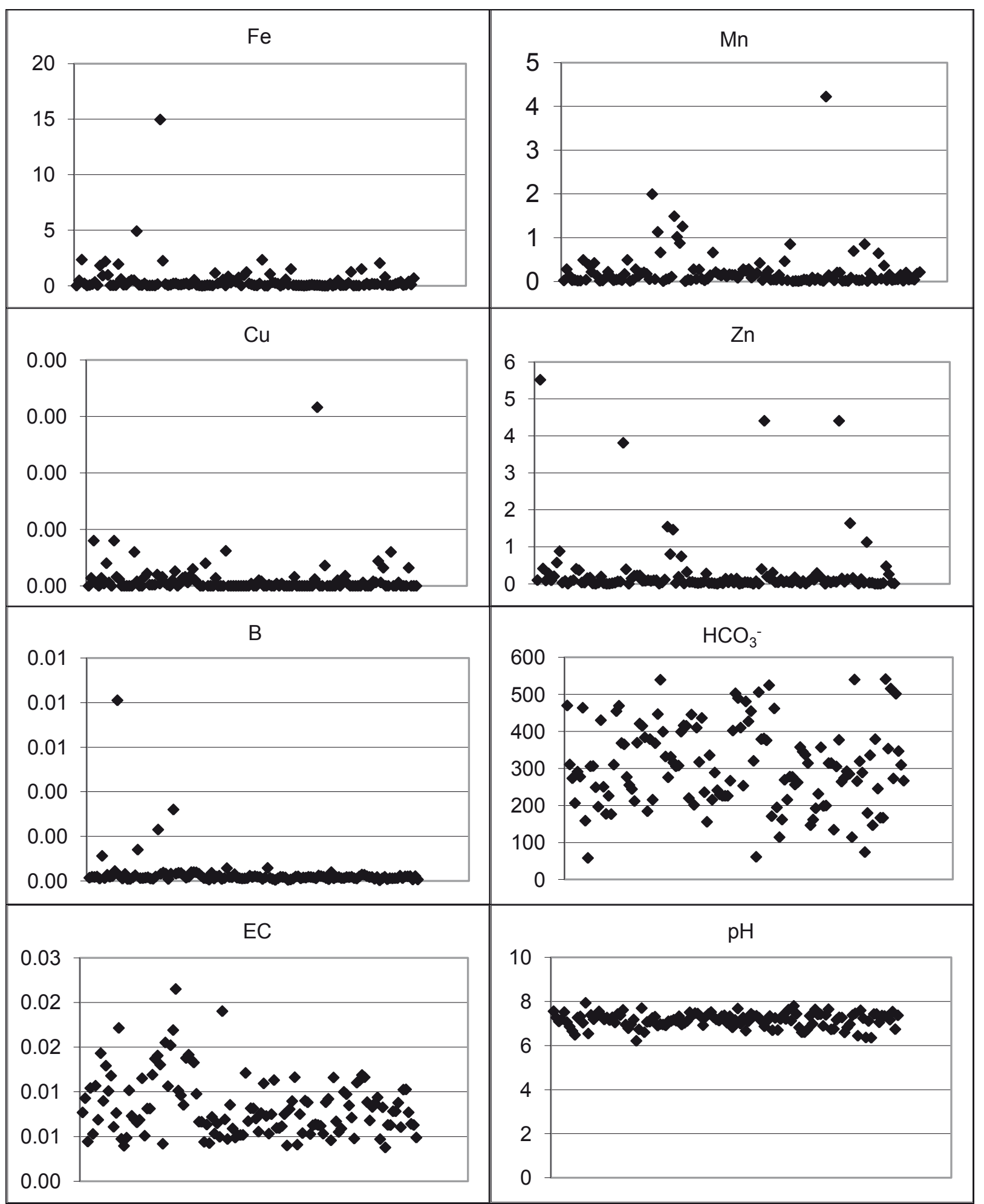

Figure 2. Chemical composition of water samples $\left(\mathrm{mg} \mathrm{dm}^{-3}\right), \mathrm{EC}\left(\mathrm{mS} \mathrm{cm}^{-1}\right)$ and $\mathrm{pH}$

indication of separate water quality guidelines for plug production constitutes a valuable element.

A successive assessment of water suitability for greenhouse crops and for containerised nursery crops was carried out in agreement with the recommendations of Bailey et al. (1999). Almost all examined waters met the requirements in relation to $\mathrm{Cu}, \mathrm{B}, \mathrm{Fe}, \mathrm{Cl}, \mathrm{Na}$, and $\mathrm{Ca}$ (Tab. 1). As mentioned earlier, the admissible concentrations of iron in water must be regarded as not justified. In the case of $\mathrm{S}_{-} \mathrm{SO}_{4}$ and $\mathrm{Mg}$, less than $50 \%$ of the samples met the quality requirements. The questionable 
Table 1. Assessment of water quality on the basis of recommendations of different researchers - selected factors (the $\%$ of samples not exceeding the upper value is in brackets)

\begin{tabular}{|c|c|c|c|}
\hline \multirow{3}{*}{ Parameter } & \multicolumn{2}{|c|}{$\begin{array}{l}\text { Water quality guidelines for } \\
\text { irrigation in a greenhouse } \\
\text { (Flood 1996) }\end{array}$} & \multirow{2}{*}{$\begin{array}{c}\text { Water quality for greenhouse crops } \\
\text { and for containerised nursery } \\
\text { crops (Bailey et al. 1999) }\end{array}$} \\
\hline & Recommended & $\begin{array}{l}\text { Water quality guidelines } \\
\text { for plug production }\end{array}$ & \\
\hline & & $\mathrm{mg} \mathrm{dm}^{-3}$ & \\
\hline $\mathrm{Ca}$ & $40-120(90)$ & $40-120(90)$ & $120(90)$ \\
\hline $\mathrm{Mg}$ & $6-25(46)$ & $6-25(46)$ & $24(43)$ \\
\hline $\mathrm{K}$ & $0.5-5.0(68)$ & $<10(78)$ & $10(78)$ \\
\hline $\mathrm{Na}$ & $0-30(58)$ & $<40(73)$ & $69(95)$ \\
\hline $\mathrm{S}-\mathrm{SO}_{4}$ & $24-240(100)$ & $24-240(100)$ & $30(44)$ \\
\hline $\mathrm{Cl}$ & $0-50(83)$ & $<80(97)$ & $71(97)$ \\
\hline $\mathrm{Fe}$ & $1-2(95)$ & $<5(99)$ & $0.2-4.0(98)$ \\
\hline $\mathrm{Mn}$ & $0.2-0.7(93)$ & $<2(99)$ & $1(95)$ \\
\hline $\mathrm{Zn}$ & $0.1-0.2(78)$ & $<5(99)$ & $0.3(85)$ \\
\hline $\mathrm{Cu}$ & $0.08-0.15(99)$ & $<0.2(100)$ & $0.2(100)$ \\
\hline $\mathrm{B}$ & $0.2-0.5(99)$ & $<0.5(99)$ & $0.5(99)$ \\
\hline SAR & $0-4(100)$ & $<2(97)$ & - \\
\hline $\mathrm{HCO}_{3}^{-}$ & $30-50(0)$ & $30-60(1)$ & $122(3)$ \\
\hline $\mathrm{pH}$ & $5-7(29)$ & $5.5-6.5(4)$ & 5.4-7.0 (29) \\
\hline $\mathrm{EC}$ & $1.1(79)$ & - & $\begin{array}{l}1(72) \text { for substrate } \\
2(98) \text { for nursery }\end{array}$ \\
\hline
\end{tabular}

quality in about one half of the water indicates that the limits proposed by Bailey et al. (1999) are too restrictive.

Studies have shown that many plants tolerate high concentrations of ions in the root zone. In particular, it refers to the most popular vegetable plants, i.e. tomato, cucumber and pepper. Tomato does not show any symptoms of excess at the concentration of $600 \mathrm{mg} \mathrm{SO}_{4}^{-2}$ in $\mathrm{dm}^{3}$ of nutrient solution (Kowalska 2005). During the cultivation of tomato, sulphur concentrations exceeded $1000 \mathrm{mg}$ $\mathrm{S}_{-} \mathrm{SO}_{4}^{-2} \mathrm{dm}^{-3}$ of coco fibre (Breś and Ruprik 2007). However, such high contents are not recommended. According to Rożek et al. (2003), in an experiment with tomato grown in rock wool, the accumulation of nitrates in leaves and fruits increased because of the increased sulphate content (up $550 \mathrm{mg} \mathrm{SO}_{4}^{-2}$ $\mathrm{dm}^{-3}$ ) in the nutrient solution.

The low admissible level of chloride concentration is also questionable. $\mathrm{Cl}$ ion, being a microelement, is considered as one of 16 nutrients essential for plant growth. $90 \mathrm{mg} \mathrm{Cl}$ according to Górniak (2007), $138 \mathrm{Cl}$ according to Kowalczyk et al. (2008), or even $450 \mathrm{mg} \mathrm{Cl}$ in $\mathrm{dm}^{3}$ of supplied nutrient solution according to Nurzyński and Michałojć (1998) does not affect the yielding of tomato. In the substrate, in the tomato root zone, 427 -
$550 \mathrm{mg} \mathrm{Cl} \mathrm{dm}^{-3}$ was found (Nurzyński and Michałojć 1998, Jarosz 2006, Kowalczyk et al. 2008). The Sächsische Landesanstalt für Landwirtschaft (2004) recommended the concentrations $70 \mathrm{mg} \mathrm{Na} \mathrm{dm}^{-3}$ and $100 \mathrm{mg} \mathrm{Cl} \mathrm{dm}^{-3}$ as the proper values for vegetable growing in rock wool using an open system. Sonneveld (1991) argued that for plants with small sensitivity (e.g. tomato) grown in systems without nutrient recirculation, the limit value deciding water suitability should be $106 \mathrm{mg} \mathrm{Cl}, 57.5 \mathrm{mg} \mathrm{Na}$ per $1 \mathrm{dm}^{3} \mathrm{H}_{2} \mathrm{O}$ at $25 \%$ of leakage. However, the proposed guide values for sodium seem to be too low. It was found that tomato tolerated (without any harm of the yield) a concentration exceeding $200 \mathrm{mg} \mathrm{Na} \mathrm{dm}^{-3}$ in the root zone (Breś and Ruprik 2007), while cucumber accepted $140 \mathrm{mg} \mathrm{Na} \mathrm{dm}{ }^{-3}$ (Piróg et al. 2009). Total pepper and cucumber fruit yield decreased significantly with an increasing concentration of sodium and chlorides above 230 $\mathrm{mg} \mathrm{Na} \mathrm{dm}{ }^{-3}$ and $350 \mathrm{mg} \mathrm{Cl} \mathrm{dm}^{-3}$ of nutrient solution (Chartzoulakis 1995, Chartzoulakis and Klapaki 2000). According to Ayers and Westcot (1994), the EC of soil $1.7 \mathrm{mS} \mathrm{cm}^{-1}$ or water $3.3 \mathrm{mS} \mathrm{cm}^{-1}$ decreased cucumber yield by $10 \%$. Symptoms of $\mathrm{NaCl}$ excess appeared on roses when salt concentrations exited $30 \mathrm{mM} \mathrm{dm}^{-3}$ (Cabrera and Perdomo 2003). In Dutch experiments, crops were irrigated with water 
Table 2. Proposed new guide values of water for drip irrigation in the field and in greenhouses - the highest safe concentration

\begin{tabular}{|c|c|c|c|c|c|c|c|c|}
\hline $\mathrm{N}-\mathrm{NO}_{3}$ & $\mathrm{~K}$ & $\mathrm{Ca}$ & $\mathrm{Mg}$ & $\mathrm{Na}$ & $\mathrm{Cl}$ & $\mathrm{S}-\mathrm{SO}_{4}$ & $\mathrm{HCO}_{3}^{-}$ & $\mathrm{SAR}$ \\
\hline \multicolumn{9}{|c|}{$\mathrm{mg} \mathrm{dm}^{-3}$} \\
\hline 30 & 100 & 150 & 50 & 100 & 100 & 100 & 500 & $<3$ \\
\hline
\end{tabular}

containing different levels of $\mathrm{NaCl}$. The $\mathrm{EC}$ of the irrigation water ranged between 0.2 and $3.9 \mathrm{mS} \mathrm{cm}^{-1}$ at $25^{\circ} \mathrm{C}$. Carnations and chrysanthemums proved to be the least sensitive. Gerberas and hippeastrums showed a medium sensitivity and anthuriums proved to be the most sensitive to salt (Sonneveld and Voogt 1983).

Forirrigation and fertigation withoutrecirculation of the nutrient solution, the recommended admissible concentration of magnesium (24-25 mg $\mathrm{dm}^{-3}$ ) shown in Table 1 cannot be accepted. The concentration of this ion in the studied water did not exceed $62 \mathrm{mg} \mathrm{Mg} \mathrm{dm}^{-3}$, while in the nutrient solution for plants in inert media (absence of sorption complex), the concentration was within 40-70 mg Mg dm${ }^{-3}$ (Sonneveld and Straver 1994, Breś et al. 2009). Horticultural praxis indicates that their tolerance of magnesium is still higher.

The guide values for nitrogen are rarely determined. Ayers and Westcot (1994) expected miscellaneous effects (affecting susceptible crops) when the concentration of $30 \mathrm{mg} \mathrm{N}-\mathrm{NO}_{3} \mathrm{dm}^{-3}$ was exceeded. Bailey et al. (1999) recommended $10 \mathrm{mg}$ $\mathrm{N}-\mathrm{NO}_{3} \mathrm{dm}^{-3}$ as the upper limit. Ammonium and nitrate provide nitrogen to plants and they should not cause any damage at moderate levels. Nitrate and ammonium levels higher than those listed indicate that the water source may be contaminated with fertilizer or with some other contaminants. The concentration of nitrates in the studied waters was very low; $81 \%$ of the studied waters showed less than $10 \mathrm{mg}$, while $98 \%$ of water samples did not exceed $50 \mathrm{mg} \mathrm{N}-\mathrm{NO}_{3}$. A concentration higher than $30 \mathrm{mg} \mathrm{N}-\mathrm{NO}_{3} \mathrm{dm}^{-3}$ in water for irrigation in view of leaching losses and ground water contamination is not recommended. During the fertigation of horticultural plants grown in soilless cultures, the concentration of $\mathrm{N}^{-\mathrm{NO}_{3}}$ in nutrient solution usually amounted between 90 and $200 \mathrm{mg} \mathrm{N}-\mathrm{NO}_{3} \mathrm{dm}^{-3}$ (Sonneveld and Straver 1994, Breś et al. 2009).

Summing up, one must add that in Polish horticultural practice, only two of the studied waters with sodium concentrations exceeding $100 \mathrm{mg} \mathrm{Na}$ $\mathrm{dm}^{-3}$ were not recommended for plant fertigation in greenhouses. The remaining waters were utilised for irrigation of field crops and fertigation of tomato, cucumber, pepper, roses and gerbera grown in rock wool or in coconut fibre (open system). Water containing too much iron and manganese was utilised after its purification using sand filters (deironisation and demanganesation). Taking into consideration the results of water analyses (Figs 1 and 2), as well as the recommended concentrations of components in water for irrigation (Flood 1996, Bailey et al. 1999), Table 2 shows the proposed new guide values of water used for irrigation in the field and in greenhouses. The table does not contain guide value for phosphorus because its concentration in water usually is very low (Fig. 1). Phosphorus compounds are purely soluble or not soluble in water. The concentration of microelements not included in the table cannot exceed the concentrations which have been recognised as the optimal ones for the given plant species. Nutrients supplied to plants with water during irrigation should be taken into consideration when fertilization is being elaborated.

For soilless culture fertigation in an open system, the maximum ion concentrations in water cannot exceed the recommended ones in the nutrient solution for the given plant. Also, the EC value should be taken into consideration. From Table 2 , only guide values for sodium and chlorines are valid for plants grown using this technique.

Both irrigation and fertigation factors favouring blocking emitters must be taken into consideration as well (Table 3). For example, the admissible total concentration of $\mathrm{Fe}$ in water amounts to $0.5-1$ $\mathrm{mg} \mathrm{dm}{ }^{-3}$ (it corresponds to about $0.25-0.5 \mathrm{mg} \mathrm{Fe}$ solved in $\mathrm{dm}^{3}$ of water). Dissolved solids (TDS), mentioned in Table 3, are a measure of the content of all inorganic and organic substances contained in a liquid in molecular, ionized or colloidal sol suspended form. Suspended solid refers to small solid particles that remain in suspension in water as a colloid or due to the motion of the water.

Ayers and Westcot (1994) also expressed their opinion about the necessity of modifying the existing recommendations. According to those researchers, a change of 10 to 20 percent above or below a guideline value has little significance, if compared in proper perspective with other factors affecting the yield. The mentioned researchers 
Table 3. Water quality classification relative to its potential for drip emitter clogging (Bucks et al. 1979, develop by Nakayama and Bucks 1991)

\begin{tabular}{llccc}
\hline \multirow{2}{*}{ Potential problem } & \multirow{2}{*}{ Units } & \multicolumn{3}{c}{ Degree of restriction on use } \\
\cline { 3 - 5 } & & Non & Slight to moderate & Severe \\
\hline Suspended solids & $\mathrm{mg} \mathrm{dm}^{-3}$ & $<50$ & $50-100$ & $>100$ \\
\hline Total dissolved solids & $\mathrm{mg} \mathrm{dm}^{-3}$ & $<500$ & $500-2000$ & $>2000$ \\
\hline $\mathrm{Mn}$ & $\mathrm{mg} \mathrm{dm}$ & $<0.1$ & $0.1-1.5$ & $>1.5$ \\
\hline $\mathrm{Fe}$ (total) & $\mathrm{mg} \mathrm{dm}^{-3}$ & $<0.1$ & $0.1-1.5$ & $>1.5$ \\
\hline $\mathrm{H}_{2} \mathrm{~S}$ & $\mathrm{mg} \mathrm{dm}^{-3}$ & $<0.5$ & $0.5-2.0$ & $>2.0$ \\
\hline Bacterial populations & $\mathrm{No.} \mathrm{cm}^{-3}$ & $<10000$ & $10000-50000$ & $>50000$ \\
\hline
\end{tabular}

believe that if the water is used under significantly different conditions, the guidelines may need to be adjusted. Wide deviations from the assumptions might result in incorrect judgements regarding the suitability of a particular water supply, especially if it is a borderline case. When significant experience, field trials, research or observations are available, the guidelines may be modified to fit the local conditions more closely. Such an approach is visible in the USA, where for the needs of some states, specific water quality standards have been elaborated. The proposals presented above do not refer to waters planned for sprinkler irrigation because of possible foliar injury.

\section{CONCLUSIONS}

1. Criteria to be met by water admissible for irrigation and fertigation should take into consideration the regional differences in water characteristics.Adaptation of recommendations elaborated on the basis of analyses originating from other geographical and geological regions can lead to the elimination of waters possessing favourable quality parameters.

2. For irrigation of field and greenhouse crops, the following maximum concentration of components in water have been proposed as safe ones: $30 \mathrm{mg} \mathrm{N}-\mathrm{NO}_{3}, 100 \mathrm{mg} \mathrm{K}, 150 \mathrm{mg} \mathrm{Ca}, 50$ mg Mg, $100 \mathrm{mg} \mathrm{Na}, 100 \mathrm{mg} \mathrm{Cl}, 100 \mathrm{mg} \mathrm{S}-\mathrm{SO}_{4}$ and $500 \mathrm{mg} \mathrm{HCO}_{3}^{-}$in $1 \mathrm{dm}^{3}$.

3. For soilless culture fertigation in an open system, the maximum ion concentrations in water cannot exceed the recommended ones in the nutrient solution for the given plant. Also, the EC value should be taken into consideration.

4. Next to the physiological requirements of plants, one must also consider the factors that contribute to the blocking of the fertigation systems, especially iron, manganese and dissolved solids.

\section{REFERENCES}

Ayers R.S., Westcot D.W., 1994. Water quality for agriculture. FAO Irrigation and drainage Paper 29, Rev. 1. http:/www.fao.org/DOCREP/003/ T0234E/T0234E00.htm.

Bailey D., Bilderback T., Bir D., 1999. Water considerations for container production of plants. Hort. Info. Leaflet, North Carolina State University, \#557.

Bauder T.A., Waskom R.M., DAvis J. G., 2009. Irrigation Water Quality Criteria. Fact sheet Colorado State University Extension No. 0.506:1-4.

Bar-Yosef B., Sagiv B., 1982. Response of tomatoes to $\mathrm{N}$ and water applied via the irrigation system. I. Nitrogen. Agron. J. 74: 633-637.

BRAVDO B., 1993. Root restriction by drip fertigation for high density orchards. Acta Hort. 349: 223-226.

Breś W., Golcz A., Komosa A., Kozik E., Tyksiński W., 2009. Żywienie roślin ogrodniczych. Wyd. AR im. A. Cieszkowskiego w Poznaniu: 184-190.

Breś W., Ruprik B., 2007. Uprawa drobnoowocowych odmian pomidora szklarniowego we włóknie kokosowym przy zróżnicowanym nawożeniu azotem i potasem Część III. Akumulacja składników w podłożu Acta Agroph. 9(2): 285-296.

Bucks D.A., Nakayama D.S., Gilbert R.G., 1979. Trickle irrigation water quality and preventive maintenance. Agric. Water Manag. 2: 149-162.

Cabrera R., Perdomo P., 2003. Reassessing the salinity tolerance of greenhouse roses under soilless production conditions. HortSci. 38(4): 533-536.

Chartzoulakis K., 1995. Salinity effects on fruit quality of cucumber and egg-plant. Acta Hort. 379: 187-192.

Chartzoulakis K., Klapaki G., 2000. Response of two greenhouse pepper hybrids to $\mathrm{NaCl}$ salinity during different growth stages. Sci. Hort. 86: 247-260.

DzienNik Ustaw Nr 32-1734, Poz. 284, 2004. Rozporządzenie Ministra Środowiska z dnia 11 lutego 2004 r. w sprawie klasyfikacji dla prezentowania stanu wód powierzchniowych i podziemnych, sposobu prowadzenia monitoringu oraz sposobu interpretacji wyników i prezentacji stanu tych wód. 
FLOOD D., 1996. Irrigation Water Quality for British Columbia Greenhouses. Floriculture Factsheet, April: 1-8.

GóRniaK T., 2007. Wpływ zawartości chlorków w pożywkach na plonowanie i stan odżywienia pomidora szklarniowego uprawianego w wełnie mineralnej. Rozpr. dokt. AR w Poznaniu.

Elbanowska H., Zerbe J., Siepak J., 1999. Fizycznochemiczne badania wód. Wyd. Nauk. UAM w Poznaniu.

JACKSON M.L., 1958. Soil chemical analysis. Prentice Hall. Inc. Englewood Cliffs, New York.

JAROSZ Z., 2006. Effect of different types of potassium fertilization on the yielding of greenhouse tomatoes grown in various substrates. Acta Sci. Pol. Hort. Cult. 5(1): 3-9.

Kowalczyk W., Dyśko J., Kaniszewski S., 2008. Effect of nutrient solution $\mathrm{pH}$ regulated with hydrochloric acid on the concentration of $\mathrm{Cl}^{-}$ions in the root zone in soilless culture of tomato. J. Elementol., 13(2): 245-254.

KowalsKa I., 2005. Effects of sulphate level in the nutrient solution on plant growth and sulphur content in tomato plants. Folia Hort. 17/1: 91-100.

NAKAYAMA F.S., Bucks D.A., 1991. Water quality in drip/ trickle irrigation: A review. Irrig. Sci. 12: 187-192.

NuRZYŃski J., MichaŁoJć Z., 1998. Plonowanie pomidora uprawianego na wełnie mineralnej w zależności od nawożenia potasowego. Zesz. Nauk. AR w Krakowie 333: 235-239.

Piróg J., Komosa A., Markiewicz B., 2009. The effect of wood fiber density on the content of macro and microelements in the root environment of greenhouse cucumber. Veg. Crops Res. Bull. 70: 81-89.

Rożek S., Sady W., Smoleń S., 2003. Wpływ podwyższonej zawartości siarczanów w pożywce na przemiany azotanów oraz zawartość niektórych składników w owocach pomidora (Lycopersicon esculentum Mill.). Folia Hort. 1: 501-503.

SÄchSische LANDESANSTALT FÜr LANDWIRTSCHAFt, 2004. Fachbereich Gartenbau, Anbau von Gewächshausgemüse. Dresden, pp. 219.

Sonneveld C., 1991. Rockwool as a substrate for greenhouse crops. Biotech. Agric. Forest 17: 285-311.
SonNeveld C., STraver N.B., 1994. Nutrient solution for vegetables and flowers grown in water or substrates. Voedingspolossingen glastijnbouw 8: 1-33.

Sonneveld C., Voogt W., 1983. Studies on the salt tolerance of some flower crops grown under glass. Plant Soil 74(1): 41-52.

Vomocil J.A., HaRt J., 1990. Irrigation water quality. Oregon State University Extension Service. Fertilizerguide 76: 1-3.

\section{JAKOŚĆ WODY STOSOWANEJ DO NAWADNIANIA KROPLOWEGO I FERTYGACJI ROŚLIN OGRODNICZYCH}

Streszczenie: W latach 1997-2008 poddano ocenie 131 prób wód, które stosowano lub zamierzano wykorzystać do nawadniania lub fertygacji. W wodzie oznaczano zawartość $\mathrm{N}-\mathrm{NH}_{4}$, $\mathrm{N}-\mathrm{NO}_{3}, \mathrm{P}, \mathrm{K}, \mathrm{Ca}, \mathrm{Mg}, \mathrm{Na} \mathrm{Cl}, \mathrm{S}-\mathrm{SO}_{4}, \mathrm{Fe}, \mathrm{Mn}, \mathrm{Zn}, \mathrm{Cu}$, $\mathrm{B}, \mathrm{HCO}_{3}^{-}$. Ponadto oznaczono $\mathrm{pH}$ i przewodność elektrolityczną właściwą oraz SAR. Ocenę jakości dokonano na podstawie klasyfikacji wód do nawadniania upraw szklarniowych $\mathrm{w}$ glebie lub $\mathrm{w}$ tradycyjnych podłożach. Zgodnie z wytycznymi, wody zawierały zbyt dużo składników, a szczególnie $\mathrm{HCO}_{3}^{-}, \mathrm{Mg}, \mathrm{Na}$ i K. Zakwestionowanie około $50 \%$ prób wód wskazuje, iż kryteria opracowane przez różnych autorów są zbyt restrykcyjne. Nie uwzględniają one różnic wynikających z położenia geograficznego oraz warunków geologicznych, co prowadzi do eliminacji wód dobrej jakości. Jako bezpieczne stężenia w wodzie do nawadniania lub fertygacji (uprawy polowe i szklarniowe) można przyjąć: $30 \mathrm{mg} \mathrm{N}-\mathrm{NO}_{3}, 100 \mathrm{mg} \mathrm{K}, 150 \mathrm{mg} \mathrm{Ca}, 50 \mathrm{mg}$ $\mathrm{Mg}, 100 \mathrm{mg} \mathrm{Na}, 100 \mathrm{mg} \mathrm{Cl}, 100 \mathrm{mg} \mathrm{S}-\mathrm{SO}_{4}$ i $500 \mathrm{mg}$ $\mathrm{HCO}_{3}^{-}$na $\mathrm{dm}^{3}$. Do fertygacji upraw bezglebowych w systemie otwartym maksymalne stężenia jonów w wodzie nie mogą być wyższe od stężeń zalecanych $\mathrm{w}$ pożywce dla danej rośliny $\mathrm{z}$ uwzględnieniem optymalnej wartości przewodności właściwej.

Received April 14, 2010; accepted December 17, 2010 